\section{Hip Hop in the United States}

\section{Holly Boyer}

Holly Boyer is an Information Management Expert at the Inter-American Development Bank in Washington, DC.

Correspondence concerning this column should be addressed to Aimee Graham; e-mail:aimee.graham90@gmail.com.

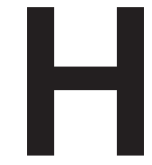

ip hop is a ubiquitous part of American society in 2015-from Kanye West announcing his future presidential bid to discussions of feminism surrounding Nikki Minaj's anatomy, to Kendrick Lamar's concert with the National Symphony Orchestra, to Questlove leading the Tonight Show Band, hip hop has exerted its influence on American culture in every way and form.

Hip hop's origin in the early 1970s in the South Bronx of New York City is most often attributed to DJ Kool Herc and his desire to entertain at a party. In the 1980s, hip hop continued to gain popularity and speak about social issues faced by young African Americans. This started to change in the 1990s with the mainstream success of gangsta rap, where drugs, violence, and misogyny became more prominent, although artists who focused on social issues continued to create. The 2000s saw rap and hip hop cross genre boundaries, and innovative and alternative hip hop grew in popularity.

Today, hip hop culture is fully integrated into American culture. Our music, fashion, film, art, politics, and society as a whole are all influenced by the genre. Hip Hop Studies is a respected academic field of study, with more colleges and universities adding courses, concentrations, and minors in the field. The following resources would be suitable for both academic and public libraries, serving adult and young adult populations, for both scholarly and personal research.

This is not intended to be a comprehensive bibliography of hip hop, as there are many excellent resources, including global reference points and international artists. Focusing solely on the United States, this collection provides the framework to begin an institutions collection.

\section{HISTORY AND CULTURE}

Chang, Jeff. Can't Stop Won't Stop. New York: St. Martin's, 2005 (ISBN: 978-0-312-42579-1)

This book is a crucial addition to any hip hop collection. While journalist Chang gives a history of hip hop, including the music, dance, and art, this book really shines is in its first-person accounts from hip hop royalty, including DJ Kool Herc (who wrote the introduction) and Afrika Bambaata, among many others. 


\section{THE ALERT COLLECTOR}

Charnas, Dan. The Big Payback: The History of the Business of Hip-Hop. New York: New American Library, 2010 (ISBN: 978-0-451-23478-0).

Charnas, a reporter who formally worked for producer and cofounder of Def Jam Records Rick Rubin, gives an insider's look at the hip-hop industry and includes excerpts from more than thre hundred interviews. The book focuses on the business of the industry, the major players over thirty years, and how hip-hop has affected mainstream/popular music and culture.

Coleman, Brian, and Adam Mansbach. Check the Technique: Volume 2. Everett, MA: Wax Facts, 2014 (ISBN: 978-09903076-0-0).

The second of this must-have series, this volume analyzes twenty-five albums from the 1980s and 1990s. Included are more than eighty interviews with some of the most influential artists during this time. It delves into the history and context of each track by speaking directly with the creators.

Fricke, Jim. Yes Yes Y'all: The Experience Music Project Oral History of the Hip-Hop's First Decade. Cambridge, MA: Da Capo, 2002 (ISBN: 978-0-306-81224-8).

Based on hip-hop exhibit at Experience Music Project in Seattle, this book traces the early history of hip hop in New York City in the early 1970s through the mid-1980s. It tells this story through photos, the DJs' and artists' and promoters' own words, and more. It also discusses hip hop's role on other artistic styles_-graffiti and break dancing in particular.

Neal, Mark Anthony, and Murray Forman. That's the Joint! The Hip-Hop Studies Reader! New York: Routledge, 2011 (ISBN: 978-0-415-87325-3).

This text, written by two university professors, is often used in Hip Hop Studies and other university courses. It includes not only a history of hip hop, but also discusses gender and misogyny, racial diversity, cultural and global impact, and hip hop's role in American politics.

Nelson, George. Hip Hop America. New York: Penguin, 2005 (ISBN: 978-0-14-303515-2).

Originally published in 1998, this revised edition with a new author introduction gives a first-hand account of the rise of hip hop, from the late 1970s Sugar Hill Gang through the late 1990s Puff Daddy. He discusses the cultural impact of hip hop, which goes well beyond music.

Peterson, James Braxton. The Hip-Hop Underground and African American Culture: Beneath the Surface. New York: Palgrave Macmillan, 2014 (ISBN: 978-1-137-30524-4).

Peterson uses the concept of "the underground" to explore connections between African American literature, hip hop culture, the Underground Railroad, solitary confinement, and more.
Rose, Tricia. Black Noise: Rap Music and Black Culture in Contemporary America. Hanover, NH: University Press of New England, 1994 (ISBN: 978-0-8195-6275-3).

Tricia Rose has written several books on hip hop and music that deserve a space in your collection (Microphone Friends: Youth Music and Youth Culture and The Hip Hop Wars). Black Noise is one of her earliest and well-known books, in which she explores how rap and the hip hop movement are misunderstood and the effect have had on American culture. This is a must for any hip hop collection.

Schloss, Joseph. Making Beats: The Art of Sample-Based HipHop. Middletown, CT: Wesleyan University Press, 2004 (ISBN: 978-0-8195-6695-9).

An academic look at hip hop production, including interviews with producers and artists explaining how they work and why they make the musical choices they do. Schloss places production techniques within a cultural and historical context allows the reader a peak into the hip hop community.

Serrano, Shea, Arturo Torres, and Ice-T. The Rap Year Book: The Most Important Rap Song from Every Year Since 1979, Discussed, Debated, and Deconstructed. New York: Abrams Image, 2015 (ISBN: 978-1-4197-1818-2).

This newly released book tells the history of hip-hop through influential songs each year from 1979 to the present. Included are graphics, photos, essays by artists, and more. This book would be a valuable addition to any collection.

\section{BIOGRAPHIES AND AUTOBIOGRAPHIES}

Eminem. The Way I Am. New York: Plume 2009 (ISBN: $978-$ 0-452-29612-1).

This autobiography takes the reader through Eminem's harrowing personal and professional journey to fame and beyond. It includes photographs, drawings, and handwritten lyrics.

Jay-Z. Decoded. New York: Speigel \& Grau, 2011 (ISBN: $978-$ 0-8129-8115-5).

Jay- $Z$ is one of the most successful and prolific hip-hop artists of all time. He tells his story unapologetically and openly and includes his analysis of his music.

KRS ONE. The Gospel of Hip Hop: The First Instrument. Brooklyn: Powerhouse, 2009 (ISBN: 978-1-57687-497-4).

KRS ONE is another hip-hop pioneer, also referred to as "The Teacha." This book is part self-help manual, part philosophical treatise, part history of hip-hop. 
Piskor, Ed. Hip Hop Family Tree 1: 1970s-1981. Seattle: Fantagraphics, 2013 (ISBN: 978-1-60699-690-4).

Piskor, Ed. Hip Hop Family Tree 2: 1981-1983. Seattle: Fantagraphics, 2014 (ISBN: 978-1-60699-756-7).

Acclaimed graphic novels that began as a web comic on Boing Boing (boingboing.net), these graphic novels tell the story of the early years of hip hop starting with pioneers DJ Kool Herc, Afrika Bambaata, and MC Sha Rock and continuing with Run-DMC, The Beastie Boys, KRS One, and many more. Volume 3 was released in August 2015.

RZA. The Wu-Tang Manual. New York: Berkley, 2005 (ISBN: 978-1-59448-018-8).

An essential volume for students of hip-hop, as the WuTang Clan is one of the most influential and innovative hip-hop groups. Divided into four books and steeped in numerology, Eastern spirituality, and mysticism, the WuTang Manual includes information on each of the nine core members of the Wu-Tang Clan, with photographs and philosophy throughout.

Shakur, Tupac. The Rose That Grew from Concrete. New York: Pocket Books, 1999 (ISBN: 978-0-671-02845-9).

While this is geared toward YA, this posthumously published book of poetry by the iconic Tupac Shakur is a valuable addition to any adult or academic collection. This collection was written between 1989 and 1991, before Shakur became famous, and it includes reproductions of the handwritten originals with ideographs, drawings, and photographs.

Thompson, Ahmir "Questlove," and Ben Greenman. Mo' Meta Blues: The World According to Questlove. New York: Grand Central, 2015 (ISBN: 978-1-4555-0137-3).

This is the memoir of Ahmir "Questlove" Thompson, the Tonight Show bandleader, the Roots drummer and founder, producer, DJ, and writer. Entertaining and intelligent, he tells his story as the son of a 50s doo-wop singer, growing up in Philadelphia in the 1970s, evolving as a musician and forming the Roots, and his experiences with the artists he's worked and played with.

\section{PERIODICALS AND SERIALS}

Global Journal of Hip Hop Culture (www.wblinc.org/global -journal-of-hip-hop-culture)

This is a biannually published peer-reviewed journal that showcases art and hip hop culture. The organization that publishes the journal, World Beats and Life, is a nonprofit organization in Washington, DC, which also offers educational opportunities, panel discussions, lectures, film screenings, and more.
The Journal of Hip Hop Studies (http://jhhsonline.org)

This is an open-access, peer-reviewed, scholarly journal focused how hip hop relates to race, ethnicity, gender, justice, religion and God, culture and more. It started in 2012, but available issues date from spring 2014 .

\section{ONLINE RESOURCES}

The Boombox (http://theboombox.com)

Current information on hip-hop culture (music and fashion), including reviews of songs and sneakers, a photo gallery, and page of lists to help the initiate or hardcore fan understand relationships between a variety of people, songs, and more.

Hiphop Archive and Research Institute (http://hiphop archive.org)

The archive, started in 2002 at Harvard University, brings together a wide variety of materials (recordings, videos, photos, research, publications, interviews, etc.), categorized by themes and research initiatives. It includes a searchable bibliography of hip hop, information on their projects, and a blog written by the staff.

Recognize! Hip Hop and Contemporary Portraiture (www .npg.si.edu/exhibit/recognize/index.html)

The Smithsonian's National Portrait Gallery held an exhibit in 2008 on Hip Hop and Contemporary Portraiture

\section{XXL (www.xxlmag.com)}

This webzine covers hip-hop news, music, and lifestyle, and features up-and-coming artists. An excellent resource on staying current in the genre.

\section{TELEVISION AND FILM}

\section{Wild Style (1983)}

Produced by Charlie Ahearn and recognized as the first hip hop film, Wild Style includes appearances by Fab Five Freddy, Grandmaster Flash, Lady Pink, and the Rock Steady Crew. "Lee" George Quinones, a graffiti artist, stars as "Zoro" and shows the early days of hip hop in New York City.

\section{Breakin' (1984)}

This movie tells the story of a young jazz dancer's encounter with two break dancers and their success as street dancers. This was ICE-T's film debut.

\section{Krush Groove (1985)}

Based on the early days of Def Jam Records, this film tells the story of record producer Russell Walker (based on Russell Simmons) at Krush Groove record label. Features appearances by Run-DMC, Kurtis Blow, Sheila E., LL Cool J, the Beastie Boys, New Edition, and the Fat Boys. 


\section{THE ALERT COLLECTOR}

Hustle and Flow (2005)

Starring Terence Howard as a Memphis pimp and hustler, this film follows him as he tries to achieve his dream to be hip hop artist. This film won and Academy Award for Best Original Song for Three 6 Mafia's "It's Hard Out There for a Pimp."

Something from Nothing: The Art of Rap (2012)

This documentary, directed and produced by Ice-T and co-directed by Andy Baybutt, explores the history of hip hop and artistry of creating verses through interviews with some of the most influential American hip hop artists. It includes interviews with Afrika Bambaataa, Big Daddy Kane, Dr. Dre, Eminem, Chuck Dee, Kanye West, MC Lyte, Snoop Dog, Raekwon, Nas, and many more.
Straight Outta Compton (2015)

Box office hit Straight Outta Compton tells the story of N.W.A., a hip hop group from Compton, California comprising Ice Cube, Dr. Dre, Eazy-E, MC Ren, and DJ Yella.

\section{Empire}

Hit television show on FOX, this is the story of the complicated life of Lucious Lyon, a hip hop artist and CEO of Empire Entertainment and his ex-wife Cookie.

There are several reality TV shows related to hip-hop that are currently or recently showing. These include:

- Love and Hip Hop and Love and Hip Hop Atlanta on VHI

- Sisterhood of Hip Hop on Oxygen

- Growing Up Hip Hop on WE tv 